\title{
Two rare halophyte species: Aster tripolium L. and Plantago maritima L. on the Baltic coast in Poland - their resources, distribution and implications for conservation management
}

\author{
Magdalena Lazarus* \& Katarzyna Wszałek-Rożek
}

Department of Plant Taxonomy and Nature Conservation, University of Gdańsk, Wita Stwosza 59, 80-308 Gdańsk, Poland

* corresponding author (e-mail: magdalena.lazarus@biol.ug.edu.pl)

\begin{abstract}
The paper presents the results of geobotanical studies on the distribution and resources of Aster tripolium L. and Plantago maritima L, two rare halophytes in Poland. The research was conducted in northern Poland, along the Baltic coast in 2013. The present distribution of the two species was compared with historical data and general trends of and threats to these two species were examined. In total, 33 sites of $A$. tripolium and 18 of $P$. maritima were found in the research area. The resources of both species have been perceptibly depleting during last 150 years, which is mostly due to human agencies (e.g. habitat devastation caused by growing urban areas and the change in management and/or habitat condition). In order to preserve both species, it may be necessary to start an ex situ conservation program.
\end{abstract}

Key words: endangered species; historical sites; changes in distribution; anthropopression; active conservation; GIS

\section{Introduction}

Biological diversity, defined as the variety of life on Earth including diversity within species, between species and of ecosystems has a value which should not be underestimated. The importance of the protection and preservation of biological diversity is the subject of the Convention of Biological Diversity, which has the approval of almost 200 parties. The decline in biodiversity is most evident in tropical regions, but this does not necessarily mean that it is not declining in Europe as well.

Halophyte plant species, due to their great ecological and physiological peculiarity, have been of special interest to the scientific world for many years. A great deal of research about their salt tolerance and survival strategies has been conducted and more is to come. One of the important reasons for their significance as objects of scientific study is their potential role in the rehabilitation of salt-rich wastelands (WilkonMichalska 1986). Some halophytes may be used in the future as crop plants for human consumption and as fodder plants for livestock in areas where desertification and salt-rich waste lands prevail (Ramani et al. 2006).

In some regions of Poland, halophytes are one of the most threatened groups of plants. This is especially true for obligatory halophytes. The majority of their sites occurs along the Baltic coast, less has inland locations. Unfortunately, along the Polish coast, halophytes do not have optimal conditions to grow, which is due to the exceptionally low salinity of the Baltic Sea, and the geomorphological character of the Baltic coast (dominance of the contraposted shoreline in opposition to the low-plain peat-covered coast supplied by sea water). Because halophilous flora is a component of plant communities along the Polish coast which are seminatural, the appropriate land use is required for their preservation (Herbich 2004; Błaszkowska et al. 2008). In addition to the aforementioned problems, one can also add human agencies as a threat to the existence of halophytes, namely: exchanging salt-marsh for agricultural lands and suburban gardens, expansion of urbanized areas into drained salt-flats (influence of the touristic lobby is 
very high in this region), reduction of substrate humidity and an increase in the desalting effect of precipitation as a consequence of constructing embankments around rivermouths and along the sea coast. Finally, the greatest threat of this time is posed by abandoning of grazing and mowing, which leads to expansion of glycophyte species on salt-marshes (Andersen et al. 1990). All of the aforementioned processes result in a decrease in the number of sites of halophilous flora, shrinking of their population sizes and impoverishment of their genetic reserves.

The phenomenon described above was broadly studied in 1970s and 1980s by Piotrowska $(1976,1980)$, who discovered a retreat of 10 halophilous species which had been components of Polish flora in the earlier half of the 20th century. Because of the intensity and range of changes currently caused by the cessation of mowing and grazing of salt-flats, Piotrowska's work is no longer valid, although it is still valuable as comparative data.

The main aim of the studies was to examine changes in the distribution and resources of halophytes in Poland. For this purpose, two species were chosen: Aster tripolium L. (sea aster) and Plantago maritima L. (sea plantain). The authors of this paper tried to define the nature, range and causes of the identified changes and to predict future of halophytes in the area of the Polish coast.

\section{Study species}

Two obligatory halophitous species which are rare in Polish flora were chosen for the study: Aster tripolium L. and Plantago maritima L.

A. tripolium (Asteraceae) in Poland is represented by the subspecies typicum. It is a biennial commonly found on European seashores, rarely in inland sites. It is entomophilous, although autogamy can also occur (Koutstaal et al. 1987). A. tripolium easily spreads by producing wind-dispersed seeds in large quantities. It is photophilous, grows in mineral and organic soils and has been recorded in both natural and anthropogenic habitats.

P. maritima (Plantaginaceae) is represented in Poland by the subspecies maritima. It is a photophilous, wind-pollinated, rosette herb of great phenotypic plasticity (Kuiper \& Bos 1991). Each plant produces from one to many inflorescences. The fruit is a capsule that contains one to four seeds (Nilsson \& Gren 2006). It prefers organic, moist but never long-term flooded soils. P. maritima does not demonstrate a predisposition towards expansion in Poland, and it rarely occurs in anthropogenic habitats.

Both species can be found quite abundantly along the European coast, except for most of Portugal, Spain and the Balkan Peninsula. They also grow on inland sites, although not in great numbers (Hultén \& Fries 1986). In Poland, they occur mostly along the Baltic coast; whereas only A. tripolium can be found inland (Zając \& Zając 2001; Nienartowicz \& Piernik 2004; Piernik 2012).

A. tripolium and P. maritima are strictly protected by law in Poland (Regulation 2014) and are found in the Polish red list of plant species (Zarzycki \& Szelag 2006 ) within the endangered (A. tripolium) and vulnerable (P. maritima) category. P. maritima also occurs in the Polish red book of plant species within vulnerable category (Kaźmierczakowa et al. 2014).

A. tripolium and P. maritima are mainly components of rush and meadow communities, especially Juncetum gerardii (Matuszkiewicz 2005).

\section{Material and methods}

\subsection{Study area}

The area covered by the studies consisted of the whole Baltic coast of Poland (Fig. 1) which is some 440 $\mathrm{km}$ in length and up to $25 \mathrm{~km}$ in width. Although the area is considerable, coastal populations of A. triploium and $P$. maritima are naturally restricted to a few regions with suitable habitat conditions for halophytes which is a result of the geographical and ecological specificity of the Polish coast. It should be clarified that not all the sites with halophilous flora along the Baltic coast are supplied with salt by sea waters. A few sites, deprived of connection to sea water, are supplied by salt springs and are, therefore, similar to inland sites.

The most abundant flora of halophytes on the Polish coast is concentrated in a few places (Fig. 1): 1. Around the mouth of the Oder river and the Wolin and Uznam islands; 2. In the surrounding area of Kołobrzeg city and the Rega river mouth; 3. Along the Bay of Puck; 4. Around the mouth of the Visula river; 5. Along edges of the Vistula Lagoon.

\subsection{Field studies}

The data concerning the distribution of both A. tripolium and P. maritima was obtained mainly from all the historical and recent publications the authors could find covering the period 1860-2012 (Lucas 1860; Abromeit et al. 1898-1940; Müller 1904; Preuss 1911/1912; Herweg 1914; Kulesza 1924; Abromeit et al. 1926; Czubiński 1950; Piotrowska 1957a, 1957b, 1961, 1966, 1974, 1976, 1980, 1988, 2001; Jasnowski 1962; Schwarz 1967; Ćwikliński 1977; Markowski \& Stasiak 1980; Sagin \& Machnikowski 1997; Ziarnek 1997; Grinn-Gofroń \& Ciaciura 1999; Bacieczko \& Wołejko 2000; Bosiacka \& Stępień 2001; Afranowicz \& Markowski 2004; Kalisińska et al. 2004; Lenartowicz 2005; Żółkoś et al. 2006; Bosiacka \& Stachowiak 


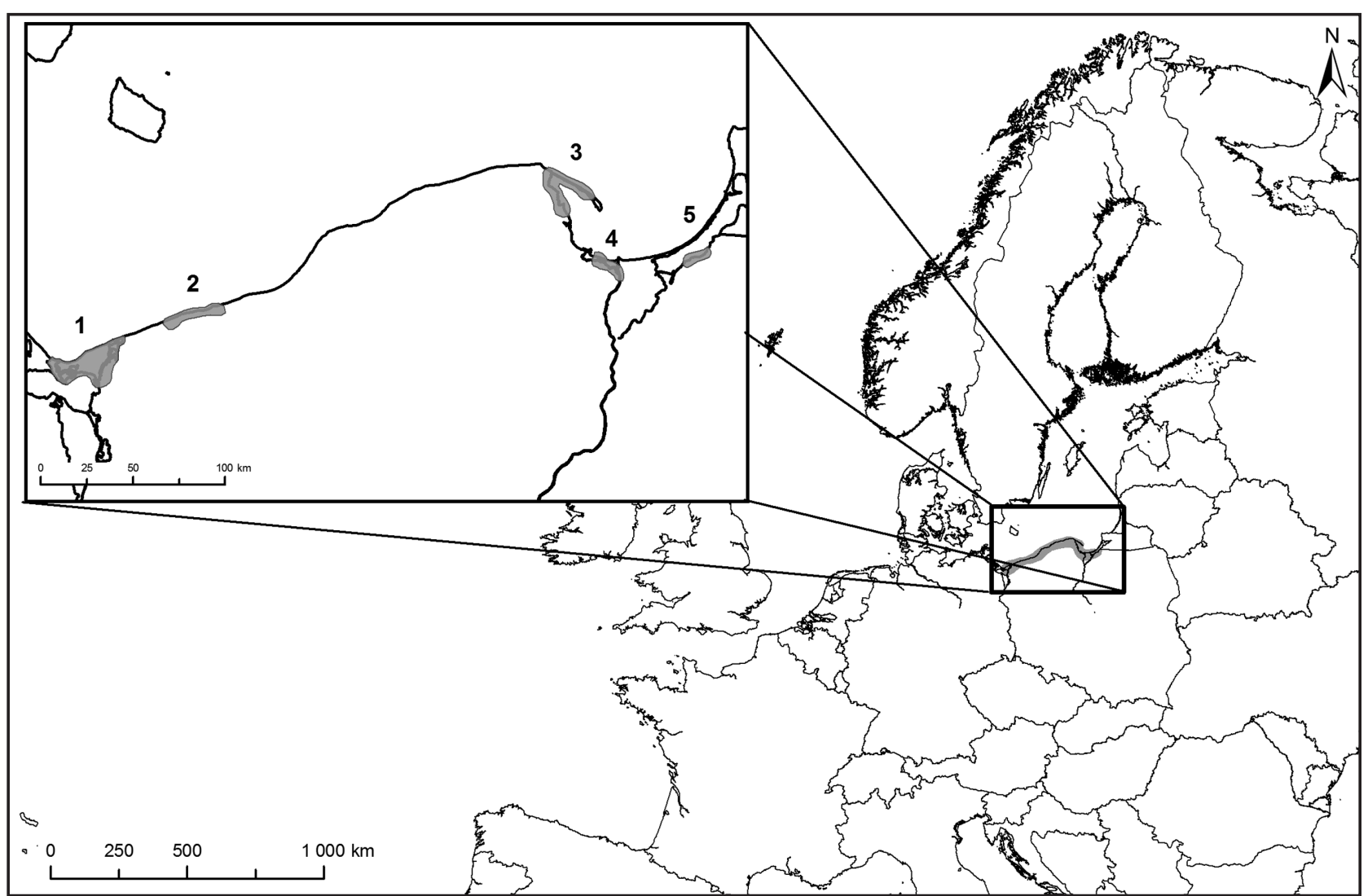

Fig. 1. Location of the study area

Explanations: 1-5 - places with the most abundant flora of halophytes on the Polish coast, 1 - the mouth of the Oder river and the Wolin and Uznam islands, 2 - surrounding area of Kołobrzeg city and the Rega river mouth, 3 - the edges of the Bay of Puck, 4 - the mouth of the Visula river, 5 - the edges of the Vistula Lagoon

2007; Wszałek-Rożek \& Markowski 2010; Bosiacka 2012). In addition, unpublished data from different scientific centres was acquired as well as from Gdańsk University and Pomeranian University in Słupsk, two Regional Directorates for Environmental Protection (in Gdańsk and in Szczecin), from the Woliński National Park, the Słowiński National Park, the Nadmorski Landscape Park and from the Polish Society for the Protection of Birds, the organization that manages two nature reserves with abundant halophilous flora. Additionally, data from UGDA herbarium was included. All the historical locations, as well as new potentially suitable sites for halophytes which were chosen on the basis of topographical maps and satellite images (Główny Urząd Geodezji i Kartografii 2012), were inserted into a GIS database and their geographical coordinates were inserted into the Garmin eTrex 30 GPS device.

The contemporary data was obtained from new field studies conducted in 2013. All of the previously known and potential localities of sea aster and sea plantain were visited. On each site, different data were obtained, namely: presence of A. tripolium or P. maritima, number of specimens (approximate number in the case of abundant populations), area of the populations, condition of specimens (number of young specimens in relation to mature ones, presence of damaged and dying specimens), type of plant communities they grew in (for this purpose, relevés were sampled according to the Zurich-Montpellier approach, Dzwonko 2007) and existing and potential threats for the population.

\subsection{Distribution data and data analyses}

All the contemporary data was inserted into the GIS database, together with the historical data. To determine if significant changes in the distribution and resources of A. tripolium and P. maritima took place, the comparative cartographic method was used. All the historical and contemporary sites were displayed on a map according to the cartogram method and using ArcGis software, version 10.0 (ESRI). The cartogram was based on the World Geodetic System ' 84 with $6 \mathrm{x}$ 6 minute grid squares (of which 104 cover the Baltic coast) divided into four smaller quadrates $3 \times 3$ minutes (Figs. 2-3). The borders of countries were based on the Corine Land Cover (European Environment Agency 2012). The nomenclature of vascular plants followed Mirek et al. (2002), whereas the nomenclature of plant 


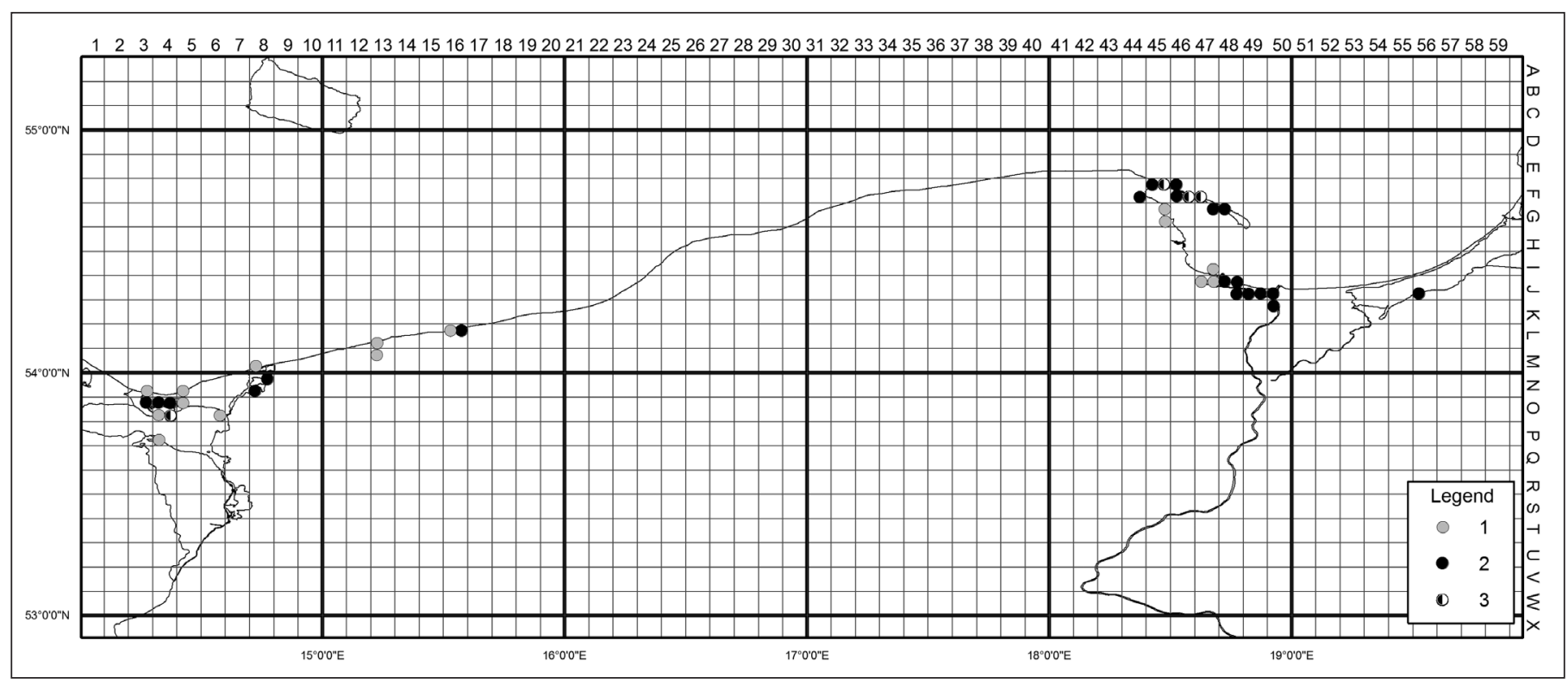

Fig. 2. Changes in the distribution of Aster tripolium along the Baltic coast in Poland

Explanations: 1 - historical localities (1980-2012), 2 - recently confirmed localities, 3 - new localities (2013)

communities was based on the work of Matuszkiewicz (2005).

Only synthetic data was presented in this paper. Relevés, in addition to the list of present-date sites with their geographic coordinations will be published in a separate paper.

\section{Results}

\subsection{Distribution and resources of halophytes}

A. tripolium was a rare species along the Baltic coast in Poland. In total, 55 localities of this taxa were found there in 26 mapping quadrates between 1860 and 2013 (Fig. 2). The authors of this paper confirmed only 33 of them (2013). Although the presence of the species was not confirmed in 22 localities, only in 14 of them was it certain that the absence of data was due to the actual withdrawal of the species, as a consequence of drastic changes in management and/or habitat conditions or as a result of mechanical destruction of the site. The aforementioned factors led to the extinction of A. tripolium in several localities around the cities of Gdańsk (quadrate no. 47J), Świnoujście (N3), Nowe Warpno (4P), and between Trzebusz and Mrzeżyn (13L) as well as in Kołobrzeg (16L), where halophytes used to be protected in the Wyspa Solna nature reserve, but due to poor management (mainly strict protection), they later disappeared (Piotrowska 1976). In the other localities, the populations of $A$. tripolium were very limited, and the possibility of the species disappearing were very high. One can use the Beka nature reserve, located along the Bay of Puck (45G) as an example. A few specimens of aster had been found there in the past (Lenartowicz 1996) but it no longer was growing at this location. It is possible that the species may still exist in some of the other unconfirmed localities, although it may have been overlooked (despite an intensive search) due to a particularly small number of specimens (e.g. Mechelińskie Łąki nature reserve, 45G) or inaccessibility to certain sites caused, for instance, by extensive areas occupied by reed rush (Drożkowe Łąki in Woliński National Park, 5O; the Mielin Peninsula on Uznam island, 3O). Furthermore, some historical sites were almost impossible to find due to vague descriptions of their locations (sites in Klincz, Wicko, 5O, and Międzyzdroje, 5N).

From among all the confirmed or newly-found localities, the most abundant resources of $A$. tripolium were located near the Polish western border: in the Odra river mouth, especially on four islands surrounded by the Stara Świna river in the Woliński National Park (4O), and between Karsibór village and the Karsiborska Kępa nature reserve (4O), where more than one thousand specimens were growing. Similarly, numerous populations could be found along the Bay of Puck (44F, 45F, $47 \mathrm{G}, 48 \mathrm{G}$ ) and in the Vistula river mouth, particularly along the Dead Vistula river (47J, 48J, 49J, 50J, 50K). Less numerous sites were located in Ognica $(3 \mathrm{O}, 4 \mathrm{O})$ near the town of Świnoujście and in Tolkmicko (56J) near the eastern border of Poland, where only a few specimens were found.

Like A. tripolium, P. maritima is also a rare species along the Baltic coast in Poland with a total of 50 sites 


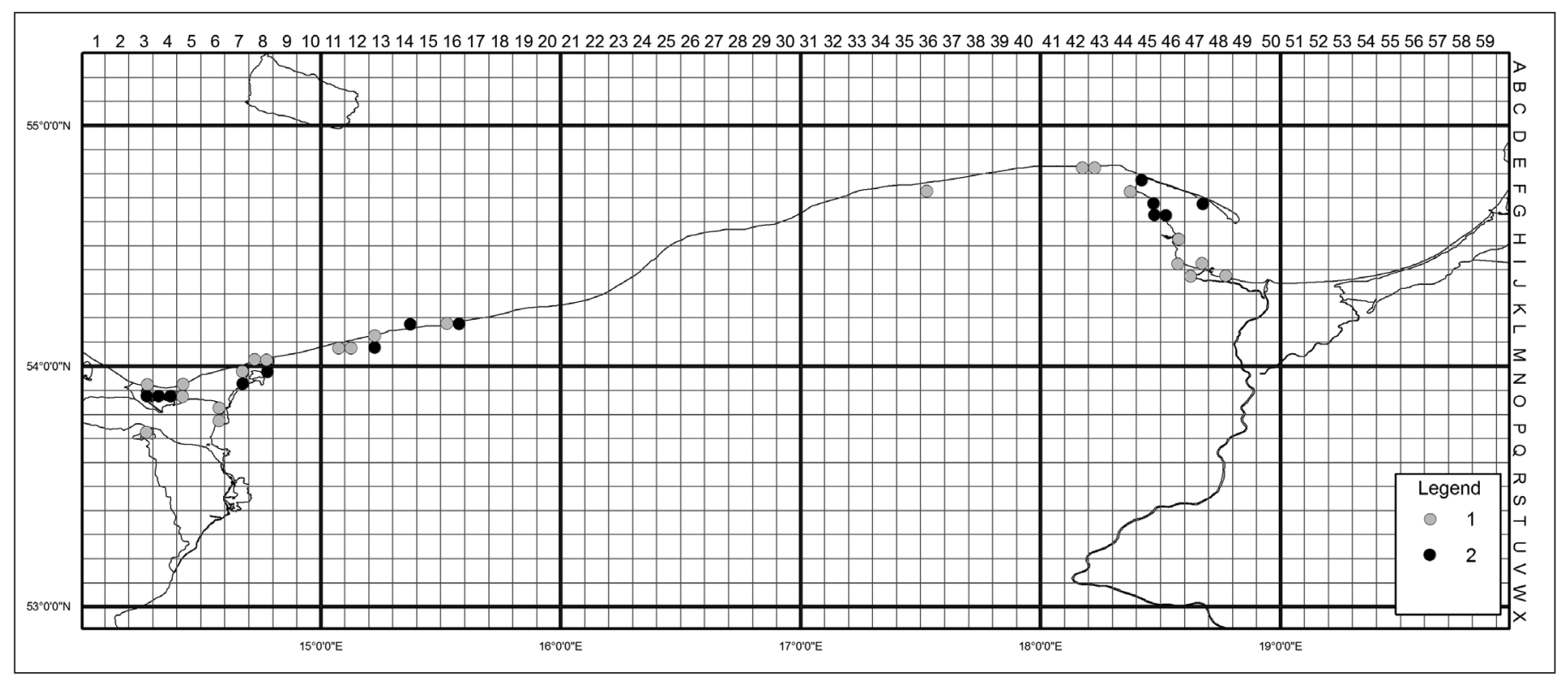

Fig. 3. Changes in the distribution of Plantago maritima along the Baltic coast in Poland Explanations: 1 - historical localities (1980-2012), 2 - recently confirmed localities

in 30 mapping quadrates (Fig. 3) found there between 1860 and 2013. Of all of the known localities, only 18 were confirmed in 2013. Although as many as 32 localities were not confirmed, one can be certain that only in 17 of them was the disappearance of P. maritima due to the same factors as previously discussed with regard to sea aster. Sites in Gdańsk and its vicinity (quadrates no. 47I and 47J) were destroyed by the expanding city. Sites located in the western part of the coast: in Wyspa Solna (16L) (which used to be a nature reserve) and Nowe Warpno (3P), as well as in Karwia (43E) located on the eastern part of the coast disappeared as a consequence of a substantial change in management and/or habitat conditions. For several historical sites, no detailed data of their location could be found in the publications, and despite intensive search, they were almost impossible to find. This refers to the sites in cities and smaller villages such as Dziwnów (8M), Ognica (3O), Międzyzdroje $(5 \mathrm{~N})$ and Dalimierz. Others, because of a particularly small number of specimens (the population in the Liwia Łuża nature reserve $11 \mathrm{M}, 12 \mathrm{M}$ and near Łeba in the Słowiński National Park 36F) could have been overlooked during the research. Finally, a few localities were inaccessible due to extensive reed rush and/ or thick shrubs (the Mielin Peninsula, 3O).

The richest resources of $P$. maritima along the Baltic coast in Poland were located in the Odra river mouth (western coast), specifically in the Woliński National Park (4O) and in the Karsiborska Kępa nature reserve (4O), where the species grew in vast numbers of specimens. Also, numerous populations were located in Budzistowo near the town of Kołobrzeg (16L). In the eastern part of the Polish coast, the most abundant sites were found in three nature reserves located along the Bay of Puck: Słone Laki (45F), Beka (45G) and Mechelińskie Łakki (45G). A small population of $P$. maritima appeared in the Melinek Peninsula of Uznam island (3O) as well as in Dzwirzyno (14L), Jastarnia $(47 \mathrm{G})$, Puck (44F) and Rewa (46G) villages, where only a few specimens were found.

\subsection{Habitat and phytocenotic preferences}

A. tripolium along the Baltic coast of Poland occurred in both natural and anthropogenic habitats, always on soils supplied by salt waters. It could be found mainly as a component of seminatural plant communities on muddy river banks where backwater phenomenon occurred or on peaty soils of marine banks. It also occurred on sandy soils which were periodically flooded with sea waters and profusely enriched with dead matter. In localities supplied by salt springs, aster grew on muddy soils. In all the sites, A. tripolium was found in the moistest parts such as periodically flooded lowerings. As far as the anthropogenic habitats were concerned, aster colonized marine and river bank stony reinforcements, where it could grow in cracks where dead matter was deposited by expelled water. It also occurred on weirs and along ditches as long as they remained in contact with salt waters.

A. tripolium was a component of different plant communities, mainly: Juncetum gerardii and PuccinelioSpergularietum. It occurred less frequently in Salicornietum patulae, Sciretum maritimi, Eleocharitetum palus- 
tris, Phragmitetum australis and communities from the Agropyron-Rumicion crispi alliance. With regard to the Phragmitetum australis community, A. tripolium occurred on the borders of the phytocoenoses, in parts with a lower density of reed or, alternatively, where rush was mowed. On stony embankments, $A$. tripolium was found growing in phytocoenoses with random combinations of ruderal and rush species.

A. tripolium grew both in regularly mown and/or pastured salt-marshes, as well as in the areas where land usage was abandoned but glycophytes did not dominate them. It preferred permanently, periodically flooded or at least wet places, furrowed by animals (in most cases, by wild boars).

Unlike sea aster, P. maritima occurred mostly in natural habitats, on soils supplied by salt waters. It was growing on muddy river banks and on peaty soils along marine banks. P. maritima could also be found on peaty-mineral soils in depressions behind dunes. In localities supplied with salt springs, $P$. maritima, like A. tripolium, grew on muddy soils. It readily colonized open places (e.g. furrowed by animals). As far as anthropogenic habitats were concerned, only a few specimens of $P$. maritima were found on marine embankments (in Jastarnia and Puck).

P. maritima was a component of limited plant communities, mainly Juncetum gerardii, PuccinelioSpergularietum and Salicornietum patulae, as well as communities of Agropyro-Rumicion crispi alliance dominated by Potentilla anserina/Agrostis stolonifera, or overdried salt-marshes dominated by Carex arenaria or Festuca arundinacea. Mowing and/or pasturing was crucial for the survival of the species. Equally essential was animal activity which disturbed the surface of the ground and, therefore, eliminated P. maritima competitors.

\section{Discussion}

\subsection{Some remarks about the method used in the research}

It can be noticed that the method used in this paper created some difficulties in data analysis. Frequently, the disappearance or appearance of a locality was not necessarily an effect of a retreating or spreading of the species. It could have been a result of more precise field research (the increase of sites) or have been due to a very vague description of the historical locations of the species which were, as a result, very difficult or even almost impossible to find (the decrease of sites). A further problem was caused by a different approach of the researchers to the definition of the site itself. The authors of this paper interpreted a single site as a place where specimens of a species were present and the population was isolated from others by significant differences in habitat conditions. However, as far as numerous and highly dispersed populations were concerned (e.g. along the Hel peninsula or Dead Vistula river), they were divided into a few sites according to the villages and cities they appeared in or nearby. As a result, some of the historical sites were merged into one.

Finally, the results presented in this paper illustrate the population dynamics of the chosen species rather poorly. This is due to the assumed principle to treat all data about the appearance of the species gathered between 1860 and 2012 as historical. Therefore, all the conclusions from the research based on the comparison of the current state of the resources and distribution of A. tripolium and P. maritima with the historical state should be treated with great care. However, the detailed analysis of chosen species population dynamics was not the aim of the research presented in this paper. The authors focused more on general trends and threats for those two species that occurred in the area of research.

\subsection{The threat level of the species in northern Poland}

As the results of the research show, the number of $A$. tripolium localities was, in general, decreasing during the last 150 years. The greatest changes in the resources of the species took place in the city of Gdańsk (quadrates no. 47I and 47J), where city growth claimed almost all aster sites which had been present there in the past; the natural habitats were devastated and replaced with urban constructions. Also, significant changes had be found in A. tripolium distribution taking place in the Odra river mouth, where many sites disappeared (Drożkowe Łąki in the Woliński National Park, 5O; Dziwnów, 8M; Nowe Warpno, 4P; Świnoujście, 3N). It appears that the greatest threat to this species was mostly connected with habitat devastation. The fact that $A$. tripolium was found growing in places where the participation of glycophyte species was high and colonized anthropogenic habitats confirmed the postulated thesis. Although only 4 of the 33 current stations with abundant populations of the species were protected in national parks or as nature reserves (four islands in the Świna river delta in the Woliński National Park 4O, Karsiborska Kępa 4O, Słone Łaki 45F, Ptasi Raj 48 J), equally numerous populations of A. tripolium occurred in non-protected areas. One can give the banks of Dead Vistula river (quadrates no. 48J, $49 \mathrm{~J}, 50 \mathrm{~J}, 50 \mathrm{~K}$ ) as an example, where due to the disappearance of the river current and backwater phenomenon occurring there, salinity of its water was significantly high (Jasińska 2002). Similarly, numerous specimens of A. tripolium grew along the Bay of Puck, outside nature 
reserves (quadrates no. 44F, 45F, 46F, 467F, 47G, 48G), where some new sites were even discovered in 2013. Currently, there is no vital threat to the aforementioned populations and their chances of survival are high. One should mention that, in addition to the existing nature reserves with $A$. tripolium as an element of their flora, at least two were due to be added: Bagna Rozwarowskie (quadrate no. 8N) (Ciaciura \& Stępień 1998) and Budzistowo $(16 \mathrm{~L})$.

In the case of $P$. maritima, as with A. tripolium, a significant decrease in the number of localities between 1860 and 2013 may be observed. Great changes in the species resources affected the whole Polish coast. Some of the sites disappeared as a result of destruction caused by growing urban areas. Sites within cities such as Gdynia (H46) and Gdańsk (I47, J47) can be used as examples here. Unfortunately, because sea plantain were growing only in the best-preserved salt-meadows, the greatest threat to the species was the disappearance of its habitat. Different causes overlapped here: salt-meadows were rare along the Baltic coast in Poland (see Introduction) and as a seminatural type of vegetation, they required appropriate land use for their preservation (Herbich 2004). Many sites of $P$. maritima disappeared due to changes in management and/or habitat conditions (lack of mowing and/ or grazing, meadow draining, cutting off the contact with salt water). Sites in Kołobrzeg (quadrate no. 16L), Nowe Warpno (3N), Karwia (E43) and Bielawskie Błoto (E42) can be given as examples here. Some were in a process of disappearing due to the factors listed above. This was true about the site in the Mielinek peninsula of Uznam island (3O) where specimens of $P$. maritima growing in relatively small numbers were found along the remains of a road surrounded by reed rush, or in small rifts made by wild boars where there was enough light for them to grow. What is more, the site in Dźwirzyno (14L) was also under threat: the few specimens of $P$. maritima found there may disappear because of the growing rush.

Regrettably, the problem of the cessation of mowing/grazing affected not only non-protected areas but even some nature reserves. Only 5 out of the 18 currently known sites of the species were located in protected areas: on four islands in the Świna river delta in the Woliński National Park (quadrate no. 4O) and in nature reserves: Karsiborska Kępa (4O), Słone Łąki (45F), Beka (45G) and Mechelińskie Łąki (45G). Numerous specimens of $P$. maritima could be found there. Unfortunately, current conservation actions took place only in three of those areas. In the Mechelińskie Łaki nature reserve, extensive usage of meadows was abandoned more than ten years ago (Żółkoś et al. 2006) and, as a consequence of this, the expansion of glycophytes was triggered off, which was a serious threat to the $P$. maritima population growing there. In 2013 , only a small proportion of young specimens was observed in the nature reserve where the population was generally ageing. The same problem occurred in the Słone Łaki nature reserve. Unfortunately, despite the fact that a renewed implementation of extensive land usage was crucial to the existence of halophytes in both reserves, strong opposition from local land owners made it problematic. The land owners found it more profitable to sell the land for touristic purposes (hotels, marines) than to maintain it in the form of salt-meadows. In Mechelińskie Łaki, in addition to the problems with land usage, the decrease in the ground water level further threatened the P. maritima population (Żółkoś et al. 2006).

As far as non-protected areas are concerned, there were only a few sites with fairly abundant specimens of $P$. maritima. This refers to the sites in: Karsibor village (4O), on Chrzasszczewska island (8N), in Włodarka (13M) and Budzistowo (16L).

The interesting fact was that $P$. maritima in the coastal part of Poland, unlike in other European countries (Scott \& Davison 1985), did not colonize anthropogenic habitats such as roadsides that were supplied with salt during winter to prevent icing.

\section{Conclusions}

The loss in resources of both A. tripolium and P. maritima along the Polish coast was undeniable, and was caused, in the most part, by human agencies. The salt-meadows which they had been the components of were considered to be one of the most threatened plant communities in Poland (Herbich 2004). It should be noted that some of the salt-marsh communities are listed as protected habitats in the Nature 2000 program. Because salt-flats are regarded as economic wastelands and because maintaining them as meadows or pastures is less and less profitable for land owners, it is possible that many sites outside nature reserves and national parks will disappear in the near future. In the case of A. tripolium, the threat of the species retreating was very low. This was due to the fact that the species colonized both natural and anthropogenic habitats and, although the number of A. tripolium sites was relatively small, in most cases it occurred in large numbers of specimens. Unfortunately, the future of $P$. maritima is not as certain. It is very likely that the species will remain only in a few refuges: the nature reserves and national parks where extensive land usage will continue. But even this is not certain, as far as Mechelińskie Łąki and Słone Łąki nature reserves are concerned (see Discussion). Although restoration of salt marshes after cessation of grazing and cutting is possible (Bakker 2012), it can 
take a long time and may not result in obtaining an ecosystem with the same plant species composition as it had before.

Nevertheless, the species preservation in the form of selected populations may not be enough. The loss of sites and specimens causes a significant reduction in genetic diversity within and among populations, and is not desirable as far as long-term conservation is concerned. We postulate that both species should be examined on a genetic level. Studies of the conservation genetics of endangered plant species are necessary to establish management plans which can then reduce the loss of biological diversity. It may also be necessary to start an ex situ conservation program.
Acknowledgements. We are grateful to all the institutions that provided data for the research, especially the Regional Directorates for Environmental Protection in Gdańsk and in Szczecin, the staff of the Woliński National Park, the Słowiński National Park and the Nadmorski Landscape Park. We are also grateful to all the aforementioned institutions, as well as to the Polish Society for the Protection of Birds for issuing permission to conduct research in protected areas (nature reserves and national parks). Our special thanks go to our colleague, Bartłomiej Hajek, for help with the field work, George Lazarus who kindly improved our English and all colleagues who provided their unpublished reports on the occurrence of the species. This research was supported by the Biology Department of Gdańsk University (project no. 538-L150-B067-13).

\section{References}

Abromeit J., Neuhoff W. \& Steffen H. 1898-1940. Flora von Ost- und Westpreussen. 1248 pp. BerlinKönigsberg.

Abromeit J., Jantzsch A. \& Vogel G. 1926. Flora von Ostund Westpreussen. 685-780 pp. Kommissionsverlag Gräfe und Unzer, Berlin-Königsberg.

Afranowicz R. \& Markowski R. 2004. Rośliny naczyniowe południowo-wschodniego obrzeża Zalewu Wiślanego (północna Polska). Acta Bot. Cassub. 4: 161-186.

Andersen H., Bakker J. P., Brongers M., Heydemann B. \& IRMLER U. 1990. Long-term changes of salt marsh communities by cattle grazing. Vegetatio 89: 137-148.

Bacieczko W. \& WoŁejko L. 2000. Rzadkie i interesujące gatunki roślin naczyniowych w wybranych gminach województwa zachodniopomorskiego. Folia Univ. Agric. Stetin 213 Agricultura 85: 7-22.

BAKKER J. P. 2012. Restoration of salt marshes. In: J. vAN Andel \& Aronson J. (eds.). Restoration ecology. The new frontier. 248-252 pp. Wiley-Blackwell.

BŁaszkowska B., Kamont P. \& Kramer-Kentzer J. 2008. Czynna ochrona podmokłych łąk nadmorskich w rezerwacie przyrody Beka. In B. BŁAszKowsKa (ed.). Czynna ochrona cennych przyrodniczo łąk i pastwisk. Doświadczenia praktyczne. 7-39 pp. OTOP.

Bosiacka B. 2012. Solniska nadmorskie (Glauco-Puccinellietalia część - zbiorowiska nadmorskie). In W. Mróz (ed.). Monitoring siedlisk przyrodniczych. Przewodnik metodyczny. Part II. pp 72-84. GIOŚ, Warszawa.

Bosiacka B. \& Stachowiak M. 2007. Spring-dotted salt marshes with Salicornia europaea (Chenopodiaceae) in the vicinity of Kołobrzeg. Fragm Flor Geobot Polonica 14(2): 337-345.

Bosiacka B. \& Stępień E. 2001. Nowe stanowiska roślinności halofilnej w Kołobrzegu. Bad Fizjogr. Pol. Zach. Seria B-Botanika 50: 117-129.
Ciaciura M. \& Stęrień E. 1998. O ochronę stanowisk woskownicy europejskiej Myrica gale L. na Bagnach Rozwarowskich. Chrońmy Przyr. Ojcz. 4(54): 14-20.

Czubiński Z. 1950. Zagadnienia geobotaniczne Pomorza. Bad. Fizjogr. Pol. Zach. 2(4): 439-648.

ĆWIKLIŃSKI E. 1977. Słonawy źródliskowe na Wyspie Chrząszczewskiej w województwie szczecińskim. Fragm. Flor. Geobot. 23(1): 57-68.

Dzwonko Z. 2007. Przewodnik do badań fitosocjologicznych. In: J. B. FALIŃSKI (ed.). Vademecum Geobotanicum, 304 pp. Sorus, Instytut Botaniki Uniwersytetu Jagiellońskiego, Poznań-Kraków.

European Environment Agency 2012 (online). Corine Land Cover [http://www.eea.europa.eu/data-andmaps/data/clc-2006-vector-data-version-3, stan na 05.01.2012].

GŁówny Urząd GeodezjI I Kartografit. 2012 (online). Geoportal krajowy [http://maps.geoportal.gov.pl, stan na 05.01.2012].

Grinn-Gofroń A. \& Ciaciura M. 1999. Zagrożone stanowisko astra solnego Aster tripolium na wyspie Karsibór. Chrońmy Przyr. Ojcz. 55(5): 87-90.

Herbich J. (ed.). 2004. Siedliska morskie i przybrzeżne, nadmorskie i śródlądowe solniska i wydmy. Poradniki ochrony siedlisk i gatunków Natura 2000 - podręcznik metodyczny. Ministerstwo Środowiska, Warszawa.

Herweg O. 1914. Flora der Kreise Neustand und Putzig in Westpreussen. Ber Westpr Bot-Zool Vereins 37: 85331.

Hultén E. \& Fries M. 1986. Atlas of North European Vascular Plants. North of the Tropic of Cancer. I. Introduction, taxonomic index to the maps 1-996. Maps 1-996. xvi+498 pp. Koeltz Scientific Books, Königstein.

JASIŃSKA E. 2002. Hydrologia i hydrodynamika Martwej Wisły i Przekopu Wisły. 133 pp. IBW PAN, Warszawa. 
JASNOwSKI M. 1962. Budowa i roślinność torfowisk Pomorza Szczecińskiego. Soc. Sci. Stet. Wydz. Nauk Przyr.Roln. 10: 1-340.

Kalisińska E., Kalisiński M. \& Popiela A. 2004. Nature vision of the Bielawki Islands and Rów Peninsula (Szczecin Lagoon) - avifauna and vascular plants flora on salt meadows and the problems of their protection. In: TH. Fock, K. Hergarden \& D. Repaŝi (eds.). Salt grasslands and coastal meadows in the Baltic region, 144-151 pp. Proceedings of the 1st conference. Schrift Fochhochschule Neubrandenburg A.

Kaźmierczakowa R., Zarzycki K. \& Mirek Z. (eds.). Polska czerwona księga roślin. Paprotniki i rośliny kwiatowe, wyd. 3, 895 pp. PAN, Instytut Ochrony Przyrody, Kraków.

Koutstaal B. P., Markusse M. M. \& De Munk W. 1987. Aspects of seed dispersal by tidal movements. In: A. H. L. Huiskes, C. W. Blom \& J. Rozema (eds.). Vegetation Between Land and Sea, pp. 226-232. Dr W. Junk publishers, Dordrecht, Netherlands.

Kuiper P. J. C. \& Bos M. (eds.). 1991. Plantago: A multidisciplinary study. Ecological Studies 89. Springer-Verlag, Berlin Heidelberg New York London Paris Tokyo Hong Kong Barcelona Budapest

Kulesza W. 1924. Strefy roślinności nadmorskiej na wybrzeżach w okolicy Rewy. Kosmos 48(3): 1-37.

Lenartowicz Z. (ed.). 1996. Monografia rezerwatu Przyrody Beka. In: M. PrzewoźNiaK (ed.). Materiały do monografii przyrodniczej regionu gdańskiego, T. I, pp: 77-173. Wydawnictwo Gdańskie, Gdańsk.

LENARTOwicz Z. 2005. Szata roślinna rezerwatu Beka. Efekty działań ochronnych. Ptasie Ostoje 9: 29-41.

LuCAs C. 1860. Flora der Insel Wollin. Verh Bot Ver Prov Brandenbg 2: 25-68.

Markowski R. \& Stasiak J. 1980. The flora of the River embankments at the mouth of the Vistula: Wisła Śmiała (Brave Vistula), Przekop Wisły (a Man-made cut). Zesz Nauk Wydz BiNoZ UG 2:117-130.

Matuszkiewicz W. 2005. Przewodnik do oznaczania zbiorowisk roślinnych Polski. In: J. B. FALIŃSKI (ed.). Vademecum Geobotanicum 3, 537 pp. Wyd. Nauk. PWN, Warszawa.

Mirek Z., Piękoś-Mirkowa H., Zając A. \& ZająC M. 2002. Flowering plants and pteridophytes of Poland. A checklist. In: Z. Mirek (ed.). Biodiversity of Poland, 1, 442 pp. W. Szafer Institute of Botany, Polish Academy of Sciences, Kraków.

Müller W. 1904. Flora von Pommern. 2. Auflage, iv+367 pp. J. Burmeister's Buchhandlung, Stettin

Nienartowicz A. \& Piernik A. 2004. *1340 Śródlądowe słone łąki, pastwiska i szuwary (Glauco-Puccinellietalia, część - zbiorowiska śródlądowe). In: J. Herbich (ed.). Siedliska morskie i przybrzeżne, nadmorskie i śródlądowe solniska i wydmy. Poradniki ochrony siedlisk i gatunków Natura 2000 - podręcznik metodyczny. T. 1, pp. 97-119. Ministerstwo Środowiska, Warszawa.

Nilsson E. \& A Gren J. 2006. Population size, female fecundity, and sex ratio variation in gynodioecious Plantago maritima. J. Evol. Biol. 19: 825-833. DOI: 10.1111/j.1420-9101.2005.01045.x
PIERNIK A. 2012. Ecological pattern of inland salt marsh vegetation in central Europe. 229 pp. UMK, Torun.

Piotrowska H. 1957a. Rezerwat "Drożkowe Łąki" na półwyspie Przytor (wyspa Wolin). Przyr. Pol. Zach. 1/2: 78-83.

Piotrowska H. 1957b. Z badań nad roślinnością halofilną wysp Wolina i Uznamu. Przyr. Pol. Zach. 1/2: 84-99.

Piotrowska H. 1961. Roślinność solniskowa pod Kołobrzegiem. Chrońmy Przyr. Ojcz. 17(4): 4-28.

Piotrowska H. 1966. Rośliny naczyniowe wysp Wolina i $\Delta$ południowego wschodniego Uznamu. PTPN Prace Kom. Biol. 30(4): 1-161.

Piotrowska H. 1974. Nadmorskie zespoły solniskowe w Polsce i problem ich ochrony. Ochr. Przyr. 39: 7-63.

Piotrowska H. 1976. Przyczyny i skutki regresywnych mian w nadmorskiej florze halofitów. In: J. B. FALIŃSKI (ed.). Synantropizacja szaty roślinnej. VI. Wymieranie składników flory polskiej i jego przyczyny. Phytocenosis 5(3/4): 237-246.

Piotrowska H. 1980. Anthropogenic changes in the distribution of halophytes in the Coastal Fringes of the Gulf of Gdańsk. Fragm. Flor. Geobot. 26(2-4): 279-297.

Piotrowska H. 1988. [R, V] Aster tripolium L. In: A. JASIEWICZ (ed.). Materiały do poznania gatunków rzadkich i zagrożonych Polski. Part I. Fragm. Flor. Geobot. 33(3-4): 290-299.

Piotrowska H. 2001. Plantago maritima. In: R. KAźMierCZAKOWA \& Z. ZARZYCKi (eds.). Polska czerwona księga roślin. Paprotniki i rośliny kwiatowe, pp. 347 348. W Szafer Institute of Botany, Polish Academy of Sciences, Kraków.

Preuss H. 1911/1912. De Vegetationsverhältnisse der Ostseeküste. Schrift D Naturf Ges. In Danzig. NF 12.1, 2:1-202.

Ramani B., Reexk T., Debez A., Stelzer R., Huchzermeyer B., Schmidt A. \& PApenBrock J. 2006. Aster trifolium L. and Sesuvium portulacastrum L.: two halophytes, two strategies to survive in saline habitats. Plant Physiology and Biochemistry 44:395-408. doi:10.1016/j. plaphy.2006.06.007

REgulation 2014. Regulation of Minister of Environment of 9 October 2014 on plant species protection. Journal of Laws 2014 item 1409.

SAçin P. \& MAchnikowski M. 1997. Plan kształtowania i ochrony szaty roślinnej Karsiborskiej Kępy. Pracowania Studiów i Projektów Prośrodowiskowych LOCUS, Gdynia.

Scott N. E. \& Davison A. W. 1985. The distribution and ecology of coastal species on roadsides. Vegetatio 62:433-440.

Schwarz Z. 1967. Badania nad florą synantropijną Gdańska i okolicy. Acta Biol. Med. Soc. Sci. Gedan 11: 363494.

Wilkoń-Michalska J. 1986. Tendencje rozwojowe i ochrona halofitów w Polsce. Acta Univ. Lodz., Folia sozol. 3: 123-129.

WsZAŁeK-RożeK K. \& Markowski R. 2010. Zróżnicowanie florystyczne zachodniego obrzeża Zatoki Puckiej (północna Polska). Acta Bot. Cassub. 7-9: 55-78. 
60 Magdalena Lazarus \& Katarzyna Wszałek-Rożek $\mid$ Two rare halophyte species: Aster tripolium L. and Plantago maritima L. on the Baltic...

ZARZYCKI K. \& SZELĄG Z. 2006. Red list of the vascular plants in Poland. In: Z. Mirek, K. Zarzycki, W. Wojewoda \& Z. Szeląg (eds.). Red list of plants and fungi in Poland, pp. 9-20. W. Szafer Institute of Botany, Polish Academy of Sciences, Kraków.

ZiARneK K. 1997. Vegetation along Szczecin Lagoon nearcoast areas. In: J. Kaliciuk \& A. Staszewski (eds.).
Birds refuges in the Polish part of Szczecin Lagoon, pp. 15-24. Zachodniopomorskie Towarzystwo Ornitologiczne, Szczecin.

ŻóŁkoś K., Bloch-OrŁowska J. \& Markowski R. 2006. Szata roślinna terenu rezerwatu "Mechelińskie Łąki" w warunkach stałej antropopresji. Acta Bot. Cassub. 6:107-120. 